NIKOLA ŽUTIĆ, naučni savetnik

Institut za savremenu istoriju

\title{
VJERSKI LIBERALIZAM I JUGOSLAVENSTVO PATRIJARHA VARNAVE I KONKORDATSKA KRIZA 1930-1938*
}

\begin{abstract}
APSTRAKT: $U$ članku se rekonstruiše vjerska aktivnost patrijarha Varnave u vremenima promjenljivih ideoloških i političkih prilika u Kraljevini Jugoslaviji - od doba njegove potpune podrške antiklerikalnom i jugoslavenskom ličnom režimu kralja Aleksandra do žestokog suprotstavljanja namjesničkom režimu kneza Pavla koji je sprovodio sve izraženiju antijugoslavensku politiku podrške rimokatolicizmu, pa tako i izglasavanju predloga konkordata u Narodnoj skupštini i Senatu.
\end{abstract}

Ključne riječi: patrijarh Varnava, jugoslavenstvo, konkordat, SPC, Vatikan, Milan Stojadinović, vjerski liberalizam

\section{Jugoslavenstvo Diktature i patrijarh Varnava 1929-1934.}

U „mirnim vremenima“ Kraljevine Jugoslavije, do 1935. godine, Srpska pravoslavna crkva (SPC) je bila državotvorna vjerska organizacija koja je podržavala postojeći frankofilski državni kurs i jugoslavensku nacionalnu ideologiju kralja Aleksandra I. Za razliku od Rimokatoličke crkve, SPC se u mnogo manjoj mjeri pojavljivala u političkom životu Kraljevine SHS, nije organizovala svoje posebne klerikalne političke partije i organizacije. Sveštenici i duhovna lica, osim npr. dr Voje Janića, nisu učestvovali u vlasti, izbornom i skupštinskom životu države.

S proglašenjem ličnog režima 1929. godine, kralj Aleksandar je počeo da sprovodi pojačanu državnu kampanju oživotvorenja ideologije jugoslavenskog nacionalizma. Ovaj ideološki koncept programski je određen

* Rad je deo projekta Srpsko društvo u jugoslovenskoj državi u 20. veku: između demokratije i diktature (177016), koji finansira Ministarstvo prosvete, nauke i tehnološkog razvoja Republike Srbije. 
kraljevim manifestom od 6. januara 1929, a zasnivao se na ideologiji integralnog jugoslavenstva, sa potpunim odbacivanjem parlamentarizma i prethodnog „partizanskog“ političkog stanja. Međutim, provođenje ovog koncepta odvijalo se sporo, pa čak i uz otpor pojedinih članova kabineta Petra Živkovića. Glasovi o političkoj nehomogenosti Živkovićeve vlade stvarali su utisak da se radi o nekakvoj koalicionoj vladi u kojoj su pojedini ministri teško odbacivali stare partijske navike. Da bi se u javnosti suzbili glasovi o nemoći vlade, neslozi ministara, i da bi se konačno krenulo sa sprovođenjem nove jugoslavenske ideologije u život, na inicijativu kralja Aleksandra i premijera Petra Živkovića sazvana je na Bledu 4. jula 1930. sjednica Ministarskog savjeta. U deklaraciji donesenoj na sjednici izraženo je jedinstvo Ministarskog savjeta i vernost svih ministara principima šestojanuarskog manifesta, isključena mogućnost uspostavljanja nekadašnjih stranaka, odnosno izražena rješenost ministara da u „budućem političkom životu samo na ovoj osnovi učestvuju, bez obzira na njihovu raniju stranačku pripadnost" ${ }^{1}$ Prvi zadatak koji je imala da ostvari vlada, prema deklaraciji od 4. jula 1930, odnosio se na stvaranje jugoslavenskih organizacija, kao i jedne političke državne jugoslovenske stranke. U prvi plan su izbili jugoslavenski Sokoli, koji su postali državna organizacija, a postepeno se stvarala i državna stranka - Jugoslovenska nacionalna stranka.

U crkvenoj sferi Dvor i državni faktori su podržali izbor Varnave Rosića za patrijarha, pa se i njegov dolazak na patrijaršijski presto desio u 1930, godini provođenja izražene jugoslavenske kampanje. Hroničar vremena Božidar Kovačević je i sam istakao da je kralj Aleksandar, poslije smrti onemoćalog patrijarha Dimitrija, ,jedva dočekao takvog patrijarha s kojim će moći sarađivati“. Kovačević je ipak naglašavao da je kralj Aleksandar bio uvjeren da je dobio poslušnog patrijarha koji će crkvu učiniti servilnim organom države, onako kako je to ponekad bilo u Srbiji, ali se iznenadio: „Novi patrijarh je znao da je došlo vreme emancipacije crkve, i da se toga ne treba plašiti nego, naprotiv, iskoristiti sve mogućnosti takve situacije". ${ }^{2}$

Srpska pravoslavna crkva je politički ispoljavala svojevrsni „klerikalni legitimizam" veličajući postojeći jugoslavenski poredak zasnovan na ideologiji građanskog liberalizma i jugoslavenskog nacionalizma. Pravoslavni crkveni poglavari, pogotovo patrijarh Varnava, bili su na poziciji ideologije jugoslavenskog nacionalizma i šestojanuarskog državotvorstva, što je nala-

\footnotetext{
${ }^{1}$ N. Žutić, Sokoli - ideologija u fizičkoj kulturi Kraljevine Jugoslavije, Beograd 1991, $37-38$

2 B. Kovačević, Srpski patrijarsi poslednjih pedeset godina, u: Srpska pravoslavna crkva 1920-1970, Spomenica o pedesetogodišnjici vaspostavljanja Srpske patrijaršije, Beograd 1970, 471.
} 
galo potrebu političke saradnje SPC sa Jugoslovenskom nacionalnom strankom i jugoslovenskim nacionalnim organizacijama (Sokolima, Narodnom odbranom, Četnicima, Kolom srpskih sestara, Udruženjem ratnika i sa drugima).

Patrijarh Varnava, koji je bio jedan od bliskih saradnika kralja Aleksandra u provođenju ideologije jugoslovenskog nacionalizma, kao važan državni čin često je isticao potrebu „sprovođenja potpunog jedinstva jednokrvne braće“. Prema riječima predsjednika Narodne odbrane Ilije Živkovića, Varnava je na svakom mjestu propovijedao jugoslavenstvo kao „nacionalno verovanje svih Srba, Hrvata i Slovenaca". ${ }^{3}$ Varnavino jugoslavensko nacionalno državotvorstvo dopunjeno je i njegovim vjerskim liberalizmom, jer je često isticao slogan „brat je mio koje vjere bio“.

Patrijarhovo liberalno jugoslavensko ideološko opredjeljenje slijedilo je i njegovo sveštenstvo, pogotovo u odnosu prema liberalnim jugoslavenskim Sokolima. Obavezu osvećenja sokolskih zastava i domova, koju je po pravilu rimokatoličko svećenstvo sabotiralo, pravoslavno sveštenstvo je pretvaralo u manifestacije odanosti Dinastiji, Otadžbini i Sokolstvu. ${ }^{4}$ Prema riječima samog patrijarha Varnave, SPC je bila „zadahnuta željom da svoju organizaciju usavrši tako kako bi prema božanskom pozivu svom mogla biti za državu i narod". Varnava je bio svjestan činjenice da će Crkva moći ispuniti svoj zavjet samo na temelju vjeroispovjedne samostalnosti uz zaštitu države. Nasuprot Rimokatoličkoj crkvi, patrijarh Varnava je tražio državnu zaštitu i državni nadzor.

U skladu sa srpskim i jugoslavenskim savezničkim i državnim vezama sa zemljama građanskog liberalizma, Srpska pravoslavna crkva je bila povezana sa crkvama građanskih demokratskih država. Iz tih razloga u SPC je bio prisutan izražen vjerski liberalizam (vjerska trpeljivost, indiferentizam, patriotski nacionalni osećaj za matičnu državu itd.). Crkveno-politički liberalizam SPC usmjerio je njenu aktivnost ka bliskoj saradnji sa protestantskim i starokatoličkim crkvama demokratskih država, koje su u isto vreme bile protivnice Vatikana i Rimokatoličke crkve. ${ }^{5}$

Srpska crkva je posebno simpatisala samostalnu Anglikansku crkvu, pa se čak radilo na tome da dođe i do dogmatskog i liturgijskog jedinstva dvije crkve. Pozdravljala je tendencije nacionalizovanja Rimokatoličke crkve u Francuskoj i jačanje "galikanizma“, podupirala stvaranje starokatoličkih narodnih crkava u Jugoslaviji i Evropi. Sve te crkve, koje su podrža-

${ }^{3}$ AJ, Zbirka Milana Stojadinovića, govor Ilije Živkovića na sahrani patrijarha Varnave 29. jula 1937.

${ }^{4}$ N. Žutić, Sokoli..., 103-104.

${ }^{5}$ Rad na zbližavanju pravoslavne, anglikanske i starokatoličke crkve, Starokatolik, glasilo Hrvatske starokatoličke crkve, br. 11, studeni 1931. 
vale postojeći frankofilski evropski poredak, solidarno su se udružile zbog netrpeljivosti prema Vatikanu, koja je proizlazila iz izraženog vatikanskog revizionizma, agresivnog klerikalizma i prozelitskog djelovanja među pravoslavnim, muslimanskim, protestantskim i jevrejskim stanovništvom Kraljevine Jugoslavije. ${ }^{6}$

Anglikanski episkopi imali su naročito bliske odnose i kontakte i sa patrijarhom Varnavom, pa su ga u više navrata posećivali u Beogradu. Tako je „Orijent ekspresom" 24. maja 1935. u Beograd stigla reprezentativna delegacija anglikanskih episkopa, teologa i javnih crkvenih radnika. Oni su sačinjavali deputaciju arhiepiskopa kenterberijskog, koja je na zvanični poziv patrijarha rumunskog putovala za Bukurešt. U Beogradu se zadržala četiri dana i tom prilikom zamoljena je audijencija kod patrijarha Varnave, koji ih je primio u Sremskim Karlovcima kao svoje lične goste. Pod visokim pokroviteljstvom Nj. sv. patrijarha u Karlovcima je održana duža konferencija anglikanaca sa najistaknutijim predstavnicima srpske bogoslovske nauke, na kojoj su se pretresala „savremena pitanja koja zanimaju hrišćanski svet kao celinu i današnje uzajamne odnose i saradnju Pravoslavlja i Anglikanstva“. Deputaciju je predvodio njegovo preosveštenstvo Frederik Hiks, sa sekretarom Džonom Daglasom, kanonikom Herbertom Šarpom i drugima. Njima na usluzi našao se predsjednik Udruženja prijatelja Velike Britanije i Amerike u Jugoslaviji episkop dalmatinski dr Irinej Đorđević.

\section{Patrijarh Varnava u opoziciji namjesničkom režimu kneza Pavla i konkordatska kriza 1935-1938}

U namjesničkom razdoblju vladavine kneza Pavla Karađorđevića nestajala je lojalnost i državotvornost SPC, prvenstveno zbog vanjskopolitičkog i unutrašnjepolitičkog zaokreta u odnosu na prethodno državno stanje, što je s vremenom proizvodilo postepeno udaljavanje nosilaca ideologije integralnog jugoslovenstva sa čelnih državnih pozicija. Obrazovanjem vlade Milana Stojadinovića, u julu 1935, za SPC su nastupila burna i nespokojna vremena. Izraženo jugoslovenstvo u redovima Srpske crkve i njena direktna podrška šestojanuarskim integralcima i nosiocima ideologije građanskog liberalizma doveli su do direktnog sukoba sa snagama koje su stvarale novi antijugoslavenski ideološki državni poredak. U cilju odbacivanja ideologije jugoslovenskog nacionalizma, vlada Milana Stojadinovića nametala je klerikalna rimokatolička i islamska (preko Mehmeda i Fehima Spahe) rješenja kao primarna u političkom životu "namjesničkog“ razdoblja. Rimokatolička crkva (RKC) djelovala je u novim povoljnijim ideološkim i

\footnotetext{
${ }^{6}$ N. Žutić, Kraljevina Jugoslavija i Vatikan, Beograd 1994, 394.
} 
političkim uslovima kao konfesija bliska vladi Milana Stojadinovića, podržavana od kneza Pavla i posebno favorizovana od rimokatoličkog dijela vlade Milana Stojadinovića. Potezi vlade, koji su išli u prilog favorizovanja RKC, izazivali su podozrenje u redovima SPC jugoslavenskih nacionalista. ${ }^{7}$

Zbog promjenjenih ideoloških i političkih uslova poslije ubistva kralja Aleksandra, već je i vlada Bogoljuba Jevtića ubrzano radila na usvajanju pripremljenog predloga konkordata. Pred napadima hijerarhije SPC predsjednik vlade M. Stojadinović se branio da su na zaključenju konkordata sa Sv. Stolicom godinama radile mnoge vlade: „Najzad se za svršenje tog pitanja angažirao i blaženopočivši Kralj Aleksandar Ujedinitelj 1933. On je lično dao prve instrukcije g. Moscatelu, naročito opunomoćenom za ove pregovore, po naredbi Kraljevoj i punomoćju potpisanom od g. B. Jevtića. Ceo tok pregovora išao je sa znanjem pok. Kralja. Najzad su pregovori završeni. To je g. Jevtić saopštio i Vatikanu i posle smrti Kraljeve nije ništa (izuzev dve beznačajne reči) promenjeno u spremljenom tekstu, kao što ni ja nisam ništa menjao u tekstu koji sam naslijedio od g. Jevtića".

Novi predsjednik vlade Milan Stojadinović uputio je već 8. jula 1935. telegram jugoslavenskom poslaniku u Rim da izvjesti Sv. Stolicu da je vlada odlučila potpisati konkordat. Kako bi dali veći značaj tom svečanom činu, „koji otvara novu eru odnosa između katoličke crkve i naše države“, Stojadinović je odlučio da kao naročitog izaslanika u Vatikan uputi ministra pravde Ljudevita Auera, koji je 25. jula 1935. potpisao konkordat, zajedno sa vatikanskim državnim sekretarom Pačelijem.

Predsjednik vlade Milan Stojadinović je zahtjevao, uoči početka redovnog januarskog zasjedanja Narodne skupštine 1936. godine, da se javno mnjenje, i naročito narodni poslanici „psihološki pripreme“ da prime konkordat, jer „nije naša namjera odugovlačiti datum ratifikacije, nego je pripremiti kako treba, a u tom smislu može nam Vatikan mnogo pomoći“. U ovom smislu Stojadinović je dao izjavu i papskom nunciju u Beogradu, a jugoslavenski diplomatski predstavnik u Vatikanu Moskatelo državnom sekretaru Pačeliju. ${ }^{9}$

Kako su procjenjivali jugoslavenski nacionalisti i hijerarhija SPC, prijedlog konkordata je omogućavao Rimokatoličkoj crkvi da zakorači u državne nadležnosti kojih se nijedna građanska država ne bi odrekla, pa se sveštenstvo na čelu sa patrijarhom Varnavom uznemirilo i onespokojilo. Jugoslavija je prema konkordatu trebalo da postane "terra misionis“ za

\footnotetext{
${ }^{7}$ N. Žutić, Sokoli - ideologija u fizičkoj kulturi Kraljevine Jugoslavije 1929-1935, Beograd 1991.

${ }^{8}$ Pismo Milana Stojadinovića - banu Savske banovine Viktoru Ružiću, 20. avgust 1937, cit prema: I. Mužić, Katolička crkva u Kraljevini Jugoslaviji, Split 1978, 224.

${ }_{9}$ AJ, Kraljevsko poslanstvo pri Sv. Stolici, telegram Milana Stojadinovića poslat u Rim 24. novembra 1935.
} 
rimokatoličke prozelite. Vezivanje Jugoslavije sa Vatikanom, preko konkordata, značilo je definitivan raskid sa zapadnoevropskim demokratizmom i laicizmom Velike Britanije i Francuske, i savezništvo sa italijanskim fašizmom. Srpska pravoslavna crkva, kao nacionalna crkva tradicionalno vezana za narodne protestantske i starokatoličke crkve evropskog zapada, osjećala se teško pogođena pravima i povlasticama koje su date hijerarhiji jedne internacionalne crkve.

Veliki protivnik konkordata Marko Cemović u svojim brošurama je isticao da je patrijarh Varnava „poveo borbu protiv konkordata u ime nezavisnosti, časti i dostojanstva Jugoslavije“. Zbog svega pretećeg, patrijarh Varnava je u julu 1937. upozorio Milana Stojadinovića da se „konkordatom ugrožavaju načela državnog suvereniteta, jer se iznad državne volje stavlja volja Rimske Kurije, koja je konkordatom mogla čitav niz pravnih pitanja u državi rješavati propisima kanonskog prava Rimokatoličke crkve“. Jugoslavija se, prema mišljenju zvanične SPC, trebala pretvoriti u podređen organ Rimske crkve, jezuitsko-fašističku koloniju, uz pomoć „bankarsko-klerikalnog" režima M. Stojadinovića. ${ }^{10}$

Zbog sprečavanja prihvatanja predloga konkordata Sveti arhijerejski sabor SPC upozoravao je predsjednika vlade M. Stojadinovića na svu pogibeljnost ratifikovanja takvog dvostranačkog međunarodnog zakona. Predstavke na adresu Milana Stojadinovića slate su već od ljeta 1935, tj. od vremena parafiranja projekta konkordata u Vatikanu 26. jula 1935. između Pija XI i predstavnika vlade. Naročito je značajna predstavka Svetog arhijerejskog sabora upućena $M$. Stojadinoviću 3. decembra (20. novembra) 1936. godine. Srpska pravoslavna crkva, koja je u kraljevinama Srbiji i Crnoj Gori zauzimala položaj državne crkve, u periodu Kraljevine Jugoslavije poštovala je proglašeno državno načelo ravnopravnosti ili pariteta vjeroispovijesti. ${ }^{11}$ Pošto je Rimokatoličkoj crkvi priznato pravo vjerskog vrhovnog poglavarstva $u$ inostranstvu, sa svima pravima i atributima nezavisnog eksteritorijalnog i ravnopravnog faktora, u predstavci je istaknuto da zbog takve privilegovane pozicije Rimske crkve, „SPC može zaštiti svoj položaj, svoja prava i interese samo u strogoj i pravičnoj ravnopravnosti zagarantovanoj Ustavom i zemaljskim zakonima“. S druge strane, u SPC su znali da je RKC „samo sebe smatrala za pravu crkvu“, pa samim time nikako nisu priznavali načelo ravnopravnosti vjeroispovijesti.

Sveti arhijerejski sabor nikako nije mogao preći preko odredbi prvog člana predloga konkordata, koji je RKC priznavao pravo da slobodno i javno vrši svoju misiju u Kraljevini, „kao da je naša Kraljevina kulturno

${ }^{10}$ N. Žutić, Sokoli, Beograd 1991.

${ }^{11}$ Pismo Sv. arhijerejskog sabora SPC - dru Milanu Stojadinoviću od 3. XII/20. XI 1936, potpisan patrijarh Varnava, Glasnik SPP, 18/1937, 15, 449-452. 
zaostala i verski neprosvećena zemlja, kojoj je potrebna misija, odnosno kao da su ostale veroispovesti u njoj objekat za misionarstvo rimokatoličke crkve“. Odredba po kojoj djeca iz mješovitih brakova „bez izuzetka moraju biti odgojena u katoličkoj vjeri“, i da se država „obavezuje da ovo javno narušavanje načela ravnopravnosti osigura prinudnim sredstvima", SPC nije nikako mogla da prihvati, pa je konflikt bio neminovan. ${ }^{12}$ Ova odluka Svetog arhijerejskog sabora, donijeta po kanonsko-zakonskim propisima, a objavljena u pismu (memorandumu) od 3. decembra 1936, nije se mogla izmjeniti bez učešća vrhovnog poglavara Srpske crkve - patrijarha Varnave.

Zahvaljujući inicijativi patrijarha Varnave, odmah poslije objelodanjivanja ove predstavke (memoranduma) na sve crkvene opštine srpskopravoslavne crkve stigli su zahtjevi da se protestnim telegramima dokumentuje jednodušnost Pravoslavne crkve protiv donošenja konkordata. Ogromna većina odbora opština SPC prihvatila je uputstva patrijarha Varnave i ostale hijerarhije, ali je bilo i slučajeva odbijanja prihvatanja takvog zahtjeva iz vrha Srpske crkve. Tako je odbor zagrebačke srpsko-pravoslavne opštine, na predlog njenog potpredsjednika dr Ivkovića, odbio slanje takvog telegramskog protesta s objašnjenjem da se crkvena opština „neće da miješa u stvari drugih vjera". ${ }^{13}$

Početkom 1937. godine na adresu zagrebačke crkvene opštine stiglo je 60 kompleta brošura o konkordatu, među kojima se nalazila „i ona poznata anonimna brošura u kojoj se napada Hrvate i govori o falsifikatu hrvatske istorije“. Taj materijal je trebalo da se podijeli svima članovima savjeta crkvene opštine, te da se tom prilikom izglasa protest, koji je prethodno „u crkvenom odboru bio propao“. Na kraju je zagrebački odbor zaključio da se te brošure ne podjele, već da se vrate Patrijaršiji, s obrazloženjem da je do Patrijaršije „kojim licima će da šalje taj materijal“. Prema subjektivnom izvještaju bana Savske banovine Viktora Ružića, na odboru je dominirala jaka opozicija protiv slanja bilo kakvog protesta, ali je ipak u izvještaju priznato da je zamjenik „odsutnog mitropolita Dositeja, prota prof. Vitković, „tek nakon završenog službenog dijela pročitao jedan brzojav koji šalje u ime vjernika patrijarh Varnava“. ${ }^{14}$

„Većina crkvene opštine“ u Zagrebu „uvjeravala je“ bana Ružića da će zadržati dotadašnji stav, tj. da se neće miješati u pitanja druge vjere, „s tim više što smatraju uređenje pitanja katoličke crkve dobitkom za državu“. Uvjeravali su ga dalje da će pravoslavno sveštenstvo u Zagrebu „voditi raču-

${ }^{12}$ Isto.

${ }^{13}$ AJ, Zbirka Milana Stojadinovića, Ban Savske banovine dr Viktor Ružić - predsjedniku vlade Milanu Stojadinoviću, Zagreb, 18. svibanj 1937.

${ }^{14}$ Isto. 
na o toj dispoziciji predstavnika svojih vjernika“. Ban Ružić je izvjestio Stojadinovića da je pravoslavni paroh u Varaždinu čak „spalio sav propagandni materijal, te uopće o tom pitanju nije vodio računa“. Radi smirenja Stojadinovića, ban Ružić ga je uvjeravao da na teritoriji zagrebačke eparhije nije zapažena „jača oporba protivu konkordata sa strane pravoslavnog klera, te štogod je urađeno u pitanju konkordata, urađeno je samo toliko da se udovolji formalno nalogu viših crkvenih vlasti“. Ružić ni u budućnosti nije očekivao bilo kakvo jače angažovanje tamošnjeg pravoslavnog sveštenstva protiv konkordata, jer su ga uvjeravali da je čak i sa „strane Nj. Sv. Patrijarha zapaženo izvjesno popuštanje u oporbi“. Čak je i Stojadinovićev vojni poslušnik, armijski general Pavle Jurišić (koji je bio na čelu zagrebačke vojne oblasti), bio ubijeđen da je konkordat „nužda državna, te da se njegovo donošenje ni u kojem slučaju ne smije sprečavati “. ${ }^{~}{ }^{2}$

Poslanik Marko Ružičić je bio jedan od rijetkih sveštenika SPC koji je, kao „jerezin“ poslanik, glasao u Narodnoj skupštini za konkordat. Svešteno lice, pravoslavni teolog i bivši ministar dr Voja Janić, takođe je kao narodni poslanik glasao za konkordat. Marko Ružičić je branio odredbe konkordata, jer one treba da „regulišu uglavnom verski položaj braće Hrvata“, ističući da „do danas katolici u ovoj zemlji, jedini od svih priznatih veroispovesti, nemaju svoj zakonom određeni položaj“. Hvalio je držanje rimokatolika i RKC prilikom donošenja Zakona o srpskoj pravoslavnoj crkvi i crkvenog Ustava, u odnosu na držanje njegove sopstvene crkve: „Poznato je nama svima da su katolici bez protesta prihvatili Ustav srpske crkve rukovođeni jednom zdravom idejom: da jednoj bratskoj narodnoj i hrišćanskoj crkvi ne treba praviti teškoće u njenom radu i razvitku...". ${ }^{16}$ Ružičić je čak branio najviše napadan član 1 konkordata o nesmetanoj misiji Rimokatoličke crkve, ističući da misiju predviđa i Ustav SPC, ne samo unutrašnju nego i spoljašnju misiju crkve „radi utvrđenja odbrane i širenja pravoslavne crkve“. Kao potvrdu svoje tvrdnje citirao je da „patrijarh upravlja crkvama i misijskim područjima u inostranstvu, gde nema organizovane pravoslavne crkve“.

Zbog izražene podrške predlogu konkordata, Sveti sinod je pretio da će Ružičića izbaciti iz crkvene organizacije. Ružičić je bio uvjeren da će biti udaljen iz SPC zbog „pretećeg“ letka Sv. arhijerejskog sinoda, pa je istakao: „Ovaj letak najbolje svedoči o mentalitetu episkopskom. Po tom letku narodni poslanik - sveštenik, ako glasa za konkordat biće stavljen pod zabranu sveštenodejstva, a zatim predat i crkvenom sudu, a građaninu poslaniku ili senatoru, koji glasa za konkordat, „da ni jedno svešteno lice, pod ma kojim izgovorom i radi ma kakvog crkveno-obrednog ( „pa valjda i

${ }^{15}$ Isto.

${ }^{16}$ AJ, Zbirka Milana Stojadinovića, JRZ - Mesni odbor za Beograd, Zemun i Pančevo, predsednik Drag. Zekavica - Gospodinu Stojadinoviću, 23. jul 1937. 
radi sahrane", dodatno ističe Ružičić) ili privatnog (!) posla, ne može ulaziti u dom bez naročite dozvole i blagoslova nadležnog episkopa".

U vreme izglasavanja konkordata Narodnoj skupštini Kraljevine Jugoslavije stizale su brojne predstavke (ukupno 275) crkvenih opština, udruženja i ustanova, srezova i opština i sela, u kojima je narod molio poslanike da se konkordat neizostavno odbaci. Sveštenstvo eparhijskog saveta Niške eparhije, svešteničko udruženje Timočke eparhije, kao i „Savez svešteničkog udruženja svete pravoslavne crkve“, u svojim predstavkama (rezolucijama) zahtjevali su da se konkordat odbaci jer se njime vređa ustavno načelo vjerske ravnopravnosti, ponižava Srpska crkva i time nanosi velika šteta naciji i državi, dok se s druge strane konkordatom Rimskoj crkvi daju neograničena prava u oblasti braka, vjerske nastave, uživanja crkvene imovine, slobodnog djelovanja preko Katoličke akcije, vjerskih redova i kongregacija. ${ }^{17}$

Jugoslavenska nacionalna organizacija Narodna odbrana zahtjevala je da se konkordat odbaci jer je izazvao veliki revolt kod svih nacionalnih organizacija, a naročito Narodne odbrane „koja po svojim pravilima ima zadatak da se stara oko podizanja nacionalne i životne snage našeg naroda“. Konkordatom su, prema zaključku Narodne odbrane, povrijeđeni državni suverenitet, vjerska ravnopravnost i sam državni Ustav, jer se njime „dozvoljava slobodno vršenje verske propagande koja slabi nacionalno jedinstvo" i zbog svih svojih mana mogao se primjeniti samo u neznabožačkim (paganskim) misionarskim zemljama. ${ }^{18}$ Narodni poslanik Dobrosav Jevđević, novinar iz Prače, koji je bio blizak Narodnoj odbrani i jugoslavenskim Četnicima, žestoko je istupao protiv konkordata i kao narodni poslanik glasao protiv njegovog usvajanja.

\section{„Krvava litija“}

Približavanje dana rasprave o konkordatu u Narodnoj skupštini, $\mathrm{u}$ javnosti je izazivalo sve veću napetost, a SPC je u nemoć, da spreči izglasavanje predloga konkordata, na ulicama Beograda 19. jula 1937. organizovala molepstvije i litiju za ozdravljenje patrijarha Varnave. Zborno mjesto odakle je u 17 sati trebalo da krene litija bila je Saborna crkva u Beogradu. U formiranoj povorci, na čelu sa pravoslavnim sveštenstvom, bili su predstavnici jugoslavenskih nacionalnih društava i ustanova, kao i brojno gra-

${ }^{17}$ AJ, Zbirka Milana Stojadinovića, Predsedništvo Ministarskog saveta - političko odeljenje, pov. br. 9-k, Referat iz pojedinih predstavki upućenih Narodnoj skupštini, Predsedništvu Narodne skupštine i Predsedništvu Kraljevske vlade, po pitanju Konkordata između naše države i katoličke crkve, s. a. (februar 1938).

${ }^{18}$ Isto. 
đanstvo. Na osnovu obavijesti da će litija biti pretvorena u političku demonstraciju, upravnik grada Beograda Aćimović zabranio je održavanje svih zborova i okupljanja do 1. augusta 1937. godine. ${ }^{19}$

I pored zabrane, ispred Saborne crkve okupilo se više hiljada ljudi i poslije molepstvija litija je organizovano krenula na čelu sa mitropolitom Platonom, vladikom šabačkim Simeonom, brojnim sveštenstvom, opozicionim političarima (pripadnicima JNS, demokrata, zemljoradnika i drugih) i nacionalnim organizacijama (Sokoli, Četnici, Narodna odbrana). Žandarmerija ministra Antona Korošeca je odmah intervenisala pa je u žestokom batinaškom nastupu, osim nekolicine građana, teže povredila i vladiku šabačkog Simeona. Narodne demonstracije su se odvijale širom Srbije, u Crnoj Gori, Bosni, Hercegovini i srpskoj Krajini. Mnogi demonstranti su kažnjavani i proganjani sve do februara 1938. kada su državne vlasti abolirale optužene.

Smrt patrijarha Varnave, koja je nastupila u vremenu skupštinskog zasjedanja o konkordatu, i dan danas je ostala neispitana zagonetka. Hrvatski istoričar Ivan Mužić je 1978. zapazio da se „pogrešno pisanje o konkordatu nastavlja i danas i u krivom prikazivanju motiva litije" i smrti patrijarha Varnave: „Prema jednom enciklopedijskom prikazu čini se, da je patrijarh Varnava umro do 19. srpnja 1937. i da je zbog toga došlo do krvavih demonstracija u Beogradu navedenog dana, iako je činjenica da je on umro poslije litije. Potom citira Rajka Veselinovića, koji je navodio da je patrijarh Varnava preminuo usred borbe sa vladom $M$. Stojadinovića, zbog čega je i pala krv u demonstracijama u Beogradu 19. VII 1937. godine".

Zvanično saopštenje crkvenih i vladinih izvora glasi da je patrijarh Varnava umro u noći kad je izglasan konkordat 23. jula. Priču o trovanju patrijarha Varnave od strane vlade „izmislili su“, prema pisanju Mužića, „velikosrpski krugovi“, a naročito „episkop Dositej i Ilija Trifunović - Birčanin“. Mužić je smatrao da Stojadinovićeva vlada nije imala ni najmanje razloga da svoju situaciju pogoršava trovanjem Varnave. ${ }^{20}$

Vijest o trovanju patrijarha Varnave, u vreme njegove teške bolesti, proturao je u javnost veliki protivnik konkordata Marko Cemović. Protiv njegove "propagande" ustao je predsjednik srpske pravoslavne crkvene opštine („u ostavci“), dr Boža Petković, koji je 22. jula 1937. izdao letak u kojem je između ostalog naveo, kao odgovor na Cemovićevu tvrdnju o trovanju, da je „sva okolina oko patrijarha sastavljena isključivo od srpskih arhijereja, pravoslavne posluge i pravoslavnih liječnika Srba i Rusa“. Međutim, istoričar Pravoslavne crkve Đoko Slijepčević je pisao da je sumnja za trovanje „pala na

${ }^{19}$ I. Mužić, Katolička crkva u Kraljevini Jugoslaviji. Politički i pravni aspekti konkordata između Sv. Stolice i Kraljevine Jugoslavije, Split 1978, 148-149.

${ }^{20}$ Isto, 164. 
dvojicu ruskih emigranata, jeromonaha Arsenija i jednog patrijarhovog kuvara, koji su nestali nakon smrti Varnave“. Slijepčević je „čuo priču“ da je Varnavu otrovao Boško Bogdanović, prijatelj Antona Korošeca, „koji se kleo da je sve to paklena izmišljotina njegovih protivnika“. Fedor Nikić je pominjao da je moguće trovanje mogla izvršiti Ljuba Škurina, ruska medicinska sestra, preko „patrijarhova sabora, što je ona kategorički pobila“. ${ }^{21}$

Mužić je, dakle, ostao uvjeren da je "trovanje Varnave“ izmišljena propaganda „velikosrpskih krugova“, pa zaključuje: „Velikosrpski elementi i danas vjeruju drukčije. Tako Milorad T. Joksimović tvrdi, da je borbu protiv konkordata platio glavom patrijarh Varnava i da su dugo kružili glasovi da ga je otrovao Korošec“. Mužić citira i svjedočenje Slovenca Joška Krošelja koji je zapisao da je ministar unutrašnjih poslova Anton Korošec „naredio dopisniku jedne ugledne inozemne agencije, koji je javio da je patrijarha otrovala vlada, da u roku od 24 sata napusti Beograd, a osobno je potpisao dekret o njegovu izgonu“. ${ }^{22}$

Patrijarh Varnava je i sam bio ubjeđen da je duže vremena trovan raznim supstancama, pa je s velikim nepovjerenjem primao hranu, koju je $u$ vrlo malim količinama uzimao pred smrt. Odmah pošto je obolio, prenesen je u svoju rezidenciju na Topčiderskom brdu. Posjete su bile dozvoljene samo liječnicima i mitropolitu Dositeju. Pošto se priča o Varnavinom trovanju širila od početka jula 1937, naređena je istraga. Naredbom uprave grada Beograda, pov. br. 198 od 2. augusta 1937, određena je liječnička komisija koja je u zajedničkom saopštenju navela da je kod Varnave „intoksikacija nastupila alimentarnim putem, i da je potom dobio zapaljenje pluća, pa nije bilo sumnje da je namjerno trovan".

Istraga o uzrocima smrti patrijarha Varnave vodila se u Okružnom sudu za grad Beograd. Zagrebački mitropolit Dositej je odbio da dođe na saslušanje, s obrazloženjem da je bolestan. U vezi svog nastupa pred sudom, Dositej se prethodno savjetovao sa Svetim sinodom, prijateljima, ali i sa Ilijom Trifunovićem - Birčaninom, koji je saslušan pred sudom i tom prilikom potvrdio da je Varnava zaista otrovan. Istražni sudija Dragoljub Avramović je potom saslušavao mitropolita Dositeja „puna tri sata“, koji je tom prilikom izjavio da je patrijarh vjerovao da je trovan. U letku „Srbina Sandžaklije“, pod naslovom „Od čega je umro naš Patrijarh Varnava“, navodi se da je patrijarha Varnavu otrovao mitropolit Dositej, „koji je u stvari Karlo Pišta, Madžar katoličke vjere, koji je u sedmoj godini prešao na pravoslavlje, kad mu se majka u Nišu preudala“. ${ }^{23}$

${ }^{21}$ Đ. Slijepčević, Istorija SPC, knj. II, str. 641.

22 J. Krošelj, Borba za konkordat i dr. Korošec, u: Svobodna Slovenija, Zbornik radova za 1966, Buenos Aires, 191.

${ }^{23}$ Arhiv SANU, br. 13586/3-6. 
Namjesništvo i režim Milana Stojadinovića na sve načine su nastojali da sakriju mogući uzrok smrti patrijarha Varnave. U socijalističkoj Jugoslaviji Varnavina smrt je takođe dugi niz godina bila tabu tema. U Spomenici izdanoj povodom 50 godina Srpske patrijaršije, vidljivi su cenzorski zahvati nad tekstom autora o ulozi patrijarha Varnave u borbi protiv prihvatanja konkordata. Istoričar crkve Kovačević uspio je da provuče samo nekoliko rečenica o Varnavinoj borbi protiv konkordata: „Patrijarh, sa Saborom, razume se, nije bio načelno protivan konkordatu, ali se nije mogao složiti sa preteranim privilegijama koje su davane rimokatoličkoj crkvi na štetu Jugoslavije i ostalih veroispovesti u državi“. Kovačević je patrijarhovo pogoršavanje zdravstvenog stanja povezao sa pogibijom kralja Aleksandra, „u čemu je on gledao rasap Jugoslavije“. Stanje u zemlji posle toga i borba oko konkordata sasvim su pogoršali njegovo zdravlje. Kovačević je na kraju naglasio da "fatalnom koincidencijom u trenucima kad je konkordat izglasavan u parlamentu, Patrijarhov se život gasio“. ${ }^{24}$

Smrti patrijarha Varnave prethodila je smrt velikog Jugoslavena biskupa kotorskog Frana Ućelinija-Ticea, koji je umro u Kotoru 1. juna 1937. godine. Pogrebu biskupa Ućelinija nije prisustvovao nijedan biskup Jugoslavije, osim po dužnosti biskup Carević, a izvinjenje je poslao biskup Dobrečić. Don Antun Milošević je u svom Dnevniku zapisao da smrt biskupa Ućelinija "mnogo žale pravoslavna braća Srbi“ na čelu sa patrijarhom Varnavom. Zbog smrti patrijarha Varnave bila je ožalošćena hijerarhija kotorske biskupije, a naročito rimokatolički svećenik don Antun Milošević. U dnevničkom zapisu od 24. jula 1937. don Milošević je zapisao da je iz Beograda u jutro radio javio da je „u ponoći prošle noći preminuo na Dedinjama srpsko-pravoslavni patrijarh Varnava nakon teškog bolovanja od 55 dana, u 58 godini života, pošto je navršio tek sedam godina od kada je postao srpsko pravoslavni patrijarh". Milošević je dalje naveo da se sa patrijarhom upoznao u Skoplju, gdje je pokojnik bio mitropolit, i to „prigodom proslave 10. godišnjice od osvojenja Skoplja“. Milošević je toj proslavi prisustvovao zajedno sa "nezaboravnim blagopokojnim našim biskupom Franom Ućelinijem“. O patrijarhu je zapisao da je bio „dobar i miroljubiv čovjek“. Potom je kao prepozit Kotorske biskupije, Svetom sinodu odmah poslao „brzojavnu sažalnicu“. Drugog dana don Milošević i don Ivo Stjepčević otišli su kod arhijerejskog namjesnika, kotorskog prote Samardžića, da mu izjave saučešće u ime kotorskog kaptola, svećenstva i biskupije. ${ }^{25}$

U Miloševićevom Dnevniku o 29. julu, danu Varnavine sahrane, zapisano je slijedeće: „U pravoslavnoj crkvi sv. Nikole, u Kotoru, u kojoj je

${ }^{24}$ B. Kovačević, $n$. d., 471-473.

${ }^{25}$ Arhiv Kotora, br. 138, „POMI“, Dnevnik Antona Miloševića, knj. IX-XX, 1 VII 1936 - 11. XII 1939. 
bio napravljen lijep katafalk sa slikom blaženop. Patrijarha Varnave, otslužena je u 9 sati zaupokojene sv. liturgija, koju je služio kotorski paroh prota Dušan Davidović, dok je na horu odgovarao ruski pjevački hor. Crkva je bila puna vjernika. - U 10 sati započeo je svečani parastos na kojem su činodejstvovali arhijerejski namjesnik Đorđe Samardžić, prota Dušan Davidović, prota Nedjeljko Cvjetković i prota prof. Jovan Lipovac. Prisustvovali su predstavnici vojnih i civilnih vlasti, raznih gradskih društava i ustanova, te veliki broj građana iz grada i okoline, koji su dupkom napunili crkvu. U zastupstvu kotorske biskupije bili smo prisutni, ja kao prepozit stolnog Kaptola, vikar kanonik dr Ivo Stjepčević i tajnik biskupskog Ordinarijata dr Lav Spoleti. Bilo je u crkvi i nekoliko građana katolika. Na horu su naizmjenice pjevali ruski hor i SPD „Jedinstvo“. Na kraju parastosa održao je lijep govor arhijerejski namjesnik prota Đorđe Samardžić, koji je vrlo jezgrovito izložio rad Nj. Sv. Patrijarha Varnave, sve od njegovog rođenja pa do prerane smrti. Na kraju govora svi prisutni u crkvi, duboko ganuti završnim riječima govornika, uskliknuli su preminulom Prvosvećeniku srpske pravoslavne crkve „Slava mu“! Govor prote Đ. Samardžića trajao je 2 časa. Svršio je ispred 11. sati prije podne". ${ }^{26}$

O stanju u Beogradu poslije smrti patrijarha Varnave ostavio je vrlo dragocjeno pismo pristalica konkordata Savica Kosanović, član Samostalne demokratske stranke, blizak srbijanskoj Udruženoj opoziciji i hrvatskim političkim grupacijama na čelu sa HSS-om. Pismo je napisano dan uoči sahrane patrijarha Varnave, 28. jula 1937. godine. Zbog značaja navodimo integralni tekst pisma: „Dragi!... Sinoć sam saznao iz prvog i najmerodavnijeg izvora slijedeće, što tebi javljam kako sam to na brzu ruku skcirao: Sinod je odobrio da se pravoslavni ministri liše svih prava u crkvi i stave pod sud i oslobode kao nedostojni zakletve, to sve ima da se pročita u svim crkvama celom narodu. Oslobođenjem od zakletve pravno se meću u škripac da ne mogu da vrše ministarsku dužnost, niti akta vlasti, pošto ustav predviđa zakletvu kao uslov vršenja ministarske dužnosti. Sem toga oni ne mogu da učestvuju u izboru patrijarha. Simeon šabački i Dositej lišili su poslanike svojih sa svojih eparhijskih teritorija prava i stavili ih pod sud, što će se pročitati u svim crkvama njihovih eparhija. Sinod je ta rešenja sankcionisao. Knez namesnik je otputovao i neće prisustvovati sahrani. Bio je poručio Sinodu da ih očekuje (u Dvoru - N. Ž.), no Sinod je odbio audijenciju sa motivacijom što im nije odgovorio na dva telegrama i dva pisma i da je već dockan za sastanak sa njim. Radi toga niko ga nije od strane sveštenstva očekivao u crkvi, a ministrima je poručeno da im se neće dopustiti pristup u crkvi, i postavljeni su čuvari da ih spreče ako dođu. Vlada je pokušala da preko namesnikovog izaslanika Joce Jovanovića („Pižona“ - N. Ž.)

\footnotetext{
${ }^{26}$ Arhiv Kotora, Dnevnik Antona Miloševića.
} 
uspostavi kontakt sa patrijaršijom, no Sinod je to odbio, jer neće sa ovom vladom da stupa u razgovor, pa je odbio da patrijarh bude sahranjen o državnom trošku. Ako se vlada ne izmeni ne može se birati patrijarh, jer ni jedan vladika neće da sedne za sto sa ovima. Crkva neće, apsolutno neće, ni po koju cenu da se koristi ovim amandmanom. Nikolaj (Velimirović - N. Ž.) je pisao ministrima pisma, strašno ih je izgrdio i Subotiću je rekao da je umro duhovno, a Stošoviću je kazao 'ako si živ javi se'. Simeon ima frakturu i zapaljenje svenoidalis“.

Kosanović je dalje zapisao da je u Beogradu zasad mirno, ali nije garantovao mir u petak 29. jula kada je trebalo da se održi sahrana. Potom se osvrnuo na mjere bezbjednosti „prošlog petka“ (22. jul) kada je izglasavan konkordat i kada su se „dobro pobrinuli za našu bezbednost“. Opisao je svoje kretanje tog i slijedećih dana: „Pod veče hoću do savinačke crkve, ali sve ulice koje tamo vode već su zatvorene i narod se ne pušta. Narodnu skupštinu na Batal Džamiji su lepo ogradili tako da svet nije mogao gore već od Miloša Velikog ulice, preko puta Londona bila je zatvorena organima bezbednosti. Po ulicama su još kasno u noći kad sam se vratio krstarili sa puškama i šlemovima, bez svake potrebe. U subotu je bilo lepo mirno, narod je odlazio u Sabornu crkvu da vidi mrtvog patrijarha. Pod veče išli smo i mi, sveta bilo mnogo pa se nismo gurali unutra, nije nas toliko interesovalo, pa nisam imao ni snage. Međutim, na kralja Petra ulici drali se neki mladići, psovali policiju, bio ceo lom, svršilo se bez većih događaja. Mi od Saborne crkve išli dole na Kalimegdan do francuskog poslanstva. Posle toga policija postala pametnija pa odredila tako da se sme samo na desnoj strani Petrovom ulicom dole i onda kroz portu prema Kalimegdanu. Svi drugi prolazi i odlazi zatvoreni. Uostalom sada to nepotrebno jer nema navale posetilaca. Svakako poseta je mnogo manja nego što pišu novine. U subotu u 10 sati izjutra otišao iz kuće gore na kraju Makenzijeve, pa polagano da vidim šta je sa zastavama. Po Makenzijevoj još ništa, tek kod Cvetnog trga prvi je istakao zastavu mali trgovac Abraham Katalan. Odmah do njega Cabaj, a onda neki Alkalaj. Uopšte Jevreji su bili prvi, državne zgrade poslednje, tek posle podne. Interesovalo me je šta ljudi misle o konkordatu, zašto se toliko uzrujavaju. Jedna naša kiradžijka, žena jednog železničara iz resavske doline, rekla je: 'Ništa na svetu ne može da me prevede na katolicizam'. Služitelj iz jednog ministarstva je rekao: 'Puki sam siromah, još od ove moje male plate mi oduzimaju, ali dok sam živ ne dam da mi uzmu krsnu slavu'. Jedan stariji čovek je melanholički uzdahnuo: 'Za pedeset godina biće ovde sve katoličko'. Narod stvarno ne zna zašto se uzrujava. Zvonilo je neprestano, ko je hteo pa je zvonio, imali su zabavu mladići, ne samo pravoslavne (vere), nego i katolici i Jevreji. Ali stvar je svakako vrlo ozbiljna. Narod se uzrujao, harangira svaki ko hoće, pojavljuju se špekulanti, propali političari, 
mračni elementi. Ministra Subotića grubo su isterali iz crkve, isti je bio slučaj sa dva narodna poslanika, u koliko je meni poznato. Sveštenici su nepopustljivi, teraju mak na konac i niko ne može predvideti šta će isterati. Svakako izgleda da se vlada Stojadinovićeva neće održati. A šta onda? Ovde se već govori o Čolak Antiću ili o Tomiću. JNS hoće da to iskoristi, demokrati su se setili dockan da bi to mogli iskoristiti. Sutra će biti sahrana, koja će proći mirno, a posle se nagoveštavaju nove bure. Mnogo mislim na Novu Riječ. Kako radite? Ja ću tu pripremati materijal i poslati. Ako možeš javi mi jednom kartom da si ovo primio i šta je sa listom. Ako nemaš vremena sam, pa neka nekoliko reči javi Lela na ime Radmile“. ${ }^{27}$

Sahrana patrijarha Varnave obavljena je 29. jula 1937. u hramu Sv. Save na Vračaru. Mitropolit Dositej je u ime Patrijaršije prethodno obavijestio Stojadinovića kao predsjednika vlade o Varnavinoj sahrani. Uoči sahrane predsjednik beogradske opštine Vlada Ilić je izdao poruku građanstvu, u kojoj je apelirao da se sačuva red, mir i dostojanstvo. Sveti arhijerejski sinod je insistirao kod vlasti da red i mir održavaju Sokoli i Četnici. Šef policije Milan Aćimović se povezao sa četničkim vojvodom Kostom Pećancem, koji mu je obećao da će lično voditi Četnike, dok se u pogledu Sokola „znalo da su oni pomirljivije raspoloženi“. Uz državne funkcionere, kraljevog izaslanika namjesnika Stankovića, pravoslavni episkopat i delegate drugih vjera, bili su i pomenuti predstavnici jugoslavenskih nacionalnih društava. Na čelu pogrebne povorke nošena je zastava iz konkordatske borbe, „na mnogo mjesta pokidana“. U svom govoru na Varnavinu pogrebu, Ilija Trifunović Birčanin je naglasio pokojnikove zasluge, hvaleći ga kao uzorna mučenika, koji je „pao u borbi protiv zla, koje pritišće narod, ruši državu i red u njoj, pljuje na svetinje i ismjehuje tradicije naroda svetosavskog“. Na kraju govora Birčanin je pozvao narod da se „zavjetuje na ustrajnu borbu za ostvarenje ideala, za koje je pao Varnava“. ${ }^{28}$

\section{Posljedice konkordatske krize i smrti patrijarha Varnave}

Kominike Uprave grada Beograda o bolesti i smrti blagoupokojenog patrijarha Varnave objavili su brojni listovi u Kraljevini Jugoslaviji. U Sarajevu je kominike izazvao brojne komentare i žučne rasprave u štampi i široj javnosti. Objavljen je u sarajevskom Jugoslovenskom listu u broju od 6. avgusta 1937. godine. Pošto se taj list rasturao u javnosti uoči dana izlaženja, za kominike se saznalo već 5 . avgusta. Kako se redakcija lista nalazila u najživljem delu centra Sarajeva (u ulici Kralja Aleksandra), stvoreno je živo inte-

${ }^{27}$ AJ, 83-1-163. Pismo „Dragi“ (Savice Kosanovića) upućeno nepoznatom adresatu (izgleda Vjećeslavu Vilderu) u Zagreb, koga autor na kraju „srdačno pozdravlja“, s. a.

${ }^{28}$ I. Mužić, n. d., 166. 
resovanje za njega, pa je iste večeri tražen za nekoliko stotina primjeraka više nego obično.

Jugoslovenska pošta, kao indirektni organ Jugoslovenske nacionalne stranke, takođe je objavila integralni kominike u broju od 6. avgusta. Kako je izvjestio dopisnik Centralnog presbiroa iz Sarajeva, „to je znatno doprinelo da su komentari bili mnogo življi u čaršiji među muslimanima. To je stvorilo uvjerenje o potpunoj tačnosti onoga što se u komunikeu veli. To uverenje pojačano je i tom okolnošću, što je komunike objavio baš taj list, koji je svojim napisima za vreme bolesti Blagoupokojenog Patrijarha, i za vreme njegove sahrane, pisao $\mathrm{u}$ istom duhu u kome su pisali svi opozicioni listovi. Slična reakcija bila je i kod srpskog građanstva, gde je ono u većini. Ali i pored toga nisu izostali komentari koji su ukazivali na pomenuti kominike kao na blef od strane vlasti. Kominike nije uspeo u ovom delu građanstva da pobije sumnju o trovanju Blagoupokojenog Patrijarha, koja se sumnja podržava isto tako i na drugoj strani. Uopšte uzev, kominike se nije živo komentarisao među Srbima, pošto je fama o trovanju među njima postala gotovo uverenje. Međutim, to uverenje nije ni juče ni danas dalo nigde povoda nekim žučnim raspravljanjima ili incidentima“. ${ }^{29}$

U izvještaju je na kraju istaknuto da sarajevsko građanstvo još uvijek komentariše sudbine onih lica koja se nalaze u policijskom pritvoru, a koja su uhapšena kao glavni podstrekači nedavnih demonstracija. Dopisnik CPB-a je pristrasno zaključio da Kominike UGB-a nije izazvao živosti ni 20\% ni na jednoj ni na drugoj strani, koliko se to očekivalo.

U telefonskom izveštaju dopisnika CPB-a iz Novog Sada, od 7. avgusta, ocjenjeno je da je diskusiju o konkordatu u Narodnoj skupštini iskoristila opozicija da povede besprimernu kampanju protiv Kraljevske vlade i parlamentarne većine: „Rasturanjem brošura i letaka, a još više usmenim širenjem alarmantnih vesti u vezi sa Konkordatom, kao i sa bolešću i smrću Patrijarha Varnave, stvorena je među pravoslavnima psihoza uznemirenosti i, donekle, neraspoloženja prema Kraljevskoj vladi i Jugoslovenskoj radikalnoj zajednici".

Međutim, poslije pogreba patrijarha Varnave, prema izvještaju iz Novog Sada, „duhovi su se počeli stišavati i pored dalje uporne agitacije opozicije, koja sada širi vesti o tobožnjem skorom padu vlade g. Stojadinovića i o obrazovanju koncentracione, neutralne ili činovničke vlade“. „Publika“ je sve manje poklanjala vjere ovakvim glasovima: „Saopštenje o uzrocima bolesti i smrti Patrijarha Varnave doneli su svi dnevni listovi ove teritorije i ovo saopštenje nesumnjivo je povoljno uticalo na čitalačku publiku, koja je naročito impresionirana stručnim mišljenjem lekara, te je i ovim u

${ }^{29}$ AJ, 38-8-33, Predsedništvo Ministarskog saveta - Centralni presbiro, Telefonski izveštaj g. Palavestre, Sarajevo, 7. avgust 1937. 
znatnoj meri poboljšana psihoza i popravljeno raspoloženje prema Kraljevskoj vladi i Jugoslovenskoj radikalnoj zajednici. U publici se i inače sve manje prepričavaju vesti i razni glasovi u vezi sa smrću Patrijarhovom" ${ }^{30}$

Varnavin nasljednik na patrijaršijskom prestolu, mitropolit Gavrilo Dožić, vodio je pomirljiviju politiku prema namjesničkom režimu kneza Pavla i vlade Milana Stojadinovića. Njegov „preobraženski govor“ od 19. avgusta 1937. izazvao je nedoumice kod pravoslavnog svijeta u katedralnoj crkvi na Cetinju. Prema telefonskom izvještaju načelnika banske uprave Cetinje Dragiše Nešovića, u govoru održanom poslije službe Božije u katedralnoj crkvi, u prisustvu oko 200 građana, Dožić je pominjao nemile slučajeve vezane za konkordat i smrt patrijarha Varnave. Osvrnuo se na svoj preobraženski govor od 19. avgusta, ističući da je „nevjerno objavljen na radiju“, tvrdeći da nije rekao „ono i onako kako se objavilo na radiju“. U svom ranijem govoru nije rekao da pravoslavna crkva stoji izvan politike, već da je zadaća crkve da vodi računa o svemu što ide na korist ili štetu pravoslavlja, naroda i države. Ponovio je da je u svom preobraženskom govoru propovjedao hrišćansku ljubav i slogu, da se ne bi razbuktavalo stanje stvoreno pitanjem konkordata; da bi se onemogućile zakulisne akcije, stvarala zabluda i zla krv. Pred narodom u crkvi je ponovio iz preobraženskog govora izgovorene riječi „o ljudima koji bi htjeli u borbi protivu konkordata da zamute vodu i da u mutnoj vodi ribu love". Dožić je izričito rekao da konkordat nije ugovor kao i drugi ugovori, niti zakon kao drugi zakoni: „Konkordat je pokušaj odvajanja crkve od države. U borbi protivu konkordata naša pravoslavna crkva neda tuđinu u našoj kući da bude tutor". Ipak je ponovio izrečeni stav iz „preobraženskog govora“: „Vera u crkvu i državu i vera u odgovorne faktore da će i ovom prilikom naći pametno rešenje i za crkvu i državu". ${ }^{31}$

„Današnji govor mitropolita Dožića“, kako je zaključio načelnik banske uprave Dragiša Nešović, „išao je naročito za tim da demantuje izvjesne izjave iz svog preobraženskog govora, ali u suštini ostaje pri svom osnovu preobraženskog govora. U današnjem svom govoru mestimičnim ubacivanjem dvosmislenih izraza, n. pr.: mesto izraza 'Vlada' - 'odgovorni faktori', upotrebljavao je samo izraz: odgovorni faktori“".

Međutim, potčinjeno sveštenstvo zetsko-crnogorske mitropolije za „nemile događaje“ direktno je optuživalo vladu Milana Stojadinovića. U svojoj propovijedi u Manastiru Drebniku kod Danilovgrada, na crkvenoj slavi dana 28. avgusta 1937, sveštenik Krsto Pavićević je rekao da je „patrijarh Varnava žrtva današnje Vlade“. Zbog takve izjave sveštenik Pavićević

${ }^{30}$ AJ, 38-8-33, Predsedništvo Ministarskog saveta - Centralni presbiro, Telefonski izveštaj dopisnika CPB-a iz Novog Sada, 7. avgust 1937.

${ }^{31}$ AJ, Zbirka Milana Stojadinovića 
je kritikovan od policijskog pisara Šaranovića i pozvan u sresko načelstvo da potvrdi svoju izjavu. U odbranu Pavićevića istupili su sveštenici Kulešević i Popović, odlaskom u sresko načelstvo, „iako nisu pozvati“. Sreski načelnik je obavio kratko saslušanje i odmah oslobodio osumnjičenog Pavićevića. Načelnik banske uprave Zetske banovine izvjestio je vladu M. Stojadinovića da na „celoj teritoriji Zetske banovine vlada red i mir.“32 Poslanici iz Zetske banovine koji su glasali za prihvatanje konkordata, uglavnom su pripadali „zelenaškom“ autonomističkom i federalističkom političkom krilu Crnogoraca (trgovac Nikola Zuber sa Cetinja, ili Đuro Čejović iz Bara, koji je bio i ministar fizičkog vaspitanja naroda u vladi Dragiše Cvetkovića 1939. godine).

Veliko uznemirenje naroda očekivalo se u užoj Srbiji na Veliku Gospojinu (28. avgusta) za kada su najavljeni brojni vjerski zborovi i gradske i seoske slave. Prema policijskim spiskovima brojne slave su se mogle pretvoriti u mjesta organizovanog antidržavnog bunta. Policija je skrenula pažnju šefu odsjeka Kraljevske banske uprave Moravske banovine, gospodinu Zlatiću, da će na crkvenu slavu u manastirima Vraćevšnica (kod Gornjeg Milanovca) i Kalenić (kod Rekovca) doći i episkop dr Nikolaj Velimirović koji će „verovatno govoriti“. U Pirot, prema najavi, na veliki sabor 28. avgusta dolazi „levi zemljoradnik“ dr Dragoljub Jovanović, vječiti opozicionar režimima monarhističke ali i republikanske Jugoslavije. Iz predostrožnosti su izdata naređenja za „preduzimanje mjera i opreza za slučaj pojave opozicionara i njihovih govora", kako bi se održao javni red i mir.

Prema izvještaju policije, u Manastiru Rakovica pored Beograda govorio je pred hiljadu lica rektor Bogoslovije u penziji Parenta. Policijski doušnik je procijenio da je u njegovom govoru „bila samo jedna teža rečenica“: „Nj. Sv. Patrijarh nije umro od Boga. Sotone su mu život uzele“. Pored te izjave Parenta je govorio o potrebi čuvanja vjere. Za vreme njegovog govora, prema izvještaju, nije bilo nijednog incidenta, a leci nisu deljeni. ${ }^{33}$

Ministar u vladi Stošović, u saopštenju Stojadinoviću, isticao je da u srezu Blace u narodu vladaju sve veći vjerski mir i spokojstvo: „Njegova (Stošovićeva) porodica danas (28. avgusta) slavi slavu. Njegov brat je kolač sam sekao. Docnije se ponudio sveštenik iz Blaca da dođe i preseče kolač. Međutim, izvešten je da je kolač već presečen. Posle toga isti sveštenik održao je pred crkvom (koja slavi), uz ogromno učešće naroda divan pomirljiv govor, rekavši između ostalog da je veliki greh i laž govoriti da narod više neće slaviti slavu i krštavati se u pravoslavnoj crkvi. To ove godine zlona-

${ }^{32}$ AJ, Zbirka Milana Stojadinovića, Telefonski izveštaj načelnika banske uprave Cetinje g. Dragiše Vešovića.

${ }^{33}$ AJ, Zbirka Milana Stojadinovića, Izvještaj za g. Predsednika Ministarskog saveta Milana Stojadinovića, s. a. 
merni političari, koji ne birajući sredstva hoće da uvuku crkvu u politiku i narod na takve klevete i laži, ne treba da se osvrće. Govor izvanredan, ostavio odličan utisak. Brat g. Stošovića zvaće sveštenika u kuću“ “ ${ }^{34}$

U Drinskoj banovini organi unutrašnje banovinske uprave takođe su preduzeli mjere opreza zbog određenih opozicionih ličnosti koji su mogli organizovati narod da krene $\mathrm{u}$ antirežimske demonstracije. Upozoreno je da će u srezu Ljubovija, na crkvenoj slavi u selu Ušavnici govoriti „jedan sveštenik - nacionalni borac". Mjesni proto u Visokom pozvao je građane da 28. avgusta zatvore radnje i izvjese crne zastave, pošto će on toga dana govoriti protiv konkordata i o stradalništvu patrijarha Varnava, a u crkvi čitati isključenje (iz crkve) ministara i narodnih poslanika. U Vardarskoj banovini praćeno je kretanje vladike skopskog Josifa Cvijovića, predratnog komite i srpskog rodoljuba, koji je 28. avgusta trebalo da posjeti Crkvu Sv. Bogorodice u selu Gornji Vrtogoš (srez pčinjski). ${ }^{35}$

Država i Srpska pravoslavna crkva, ipak, sporazumno su radili na što bržem smirenju uzavrelih vjerskih i političkih strasti. Pod pritiskom crkvenih i opštenarodnih protesta, Namjesništvo na čelu sa Pavlom Karađorđevićem ukazom br. 12381, od 8. februara 1938, dalo je opštu amnestiju za „krivična dela učinjena od strane duhovnih i svetovnih lica od 1. januara 1937. godine do dana ukaza o amnestiji, a koja su učinjena povodom podnošenja zakonskog predloga o Konkordatu“. Zastupnik predsjednika Sv. arhijerejskog sinoda poslije Varnavine smrti, mitropolit zagrebački Dositej, žalio se 19. februara vladi da se ukaz o amnestija svuda ne primjenjuje, već da se i dalje izriču i nove kazne, koje se odmah izvršuju. ${ }^{36}$ I pored slučajeva nepoštovanja amnestije, nemiri izazvani nametanjem predloga konkordata i smrću patrijarha Varnave uskoro su se u potpunosti smirili, a patrijaršijsku dužnost je odmah poslije proglašenja amnestije počeo da obavlja Gavrilo Dožić (21. februara 1938), koji je, u odnosu na patrijarha Varnavu, bio kooperativniji prema namjesničkom režimi i vladi Milana Stojadinovića.

Patrijarh Varnava je ispoljavao žestoko protivljenje donošenju konkordata jer je predosjećao, kao odličan poznavalac prozelitske suštine Rimske crkve, pogubnost i podlost politike Vatikana, koji je preko Hrvatskog katoličkog episkopata provodio prozelitsku vjersku politiku uništenja pra-

\section{${ }^{34}$ Isto.}

${ }^{35}$ AJ, Zbirka Jovana Jovanovića - Pižona, f. 32, spiskovi mjesta u kojima su se trebale održati slave i zborovi na Veliku Gospojinu 28. avgusta (izvještaji kraljevskih banskih uprava, 27. avgusta 1937).

${ }^{36}$ AJ, Ministarstvo pravde - pov. arhiva, 1-52-38, Predsedništvo Ministarskog saveta - administrativno odeljenje ministru pravde Milanu Simonoviću, str. pov. 6, 19. februar 1938. 
voslavnih Srba. Kao da je predosjećao da Vatikan nikad neće osuditi genocidne zločine koji će uskoro uslijediti u Nezavisnoj Državi Hrvatskoj, zločine inspirisane od rimokatoličke hijerarhije na čelu sa nadbiskupom Alojzijem Stepincem, koga u savremenom trenutku beatifikuje i sanktifikuje.

Nikola Žutić

\section{RELIGIOUS LIBERALISM AND PATRIARCH VARNAVA YUGOSLAVISM AND CONCORDATE CRISIS 1930-1938}

\section{Summary}

During the period of the personal regime of the King Alexander I, Varnava, the Patriarch of the Serbian Orthodox Church, clashed with antiYugoslav and clerical ideology of the Vatican and the Roman Catholic Church. Enforcing of the Concordat in mid 1930-ties has open the wide crisis in the Yugoslav political life, and moreover clash with the Serbian Orthodox Church and Yugoslav nationalist circles. Being someone who has deep knowledge of the proselyte policy of the Roman Catholic Church, the Serbian Patriarch was fiercely against it. He was afraid of the consequences of such act toward the Orthodox Church and the Serbian people in general. After the death of the Patriarch Varnava, the project of the Concordat was fully rejected by the Senate. 